\title{
DIPLOMACY AND DOGMATISM
}

\author{
Bernardino de Mendoza \\ and the French Catholic League
}





\title{
DIPLOMACY AND DOGMATISM
}

\author{
Bernardino de Mendoza \\ and the French Catholic League \\ $++*$
}

De Lamar Jensen

HARVARD UNIVERSITY PRESS

Cambridge, Massachusetts

I 964 
(C) 1964 by the President and Fellows of Harvard College All rights reserved

Distributed in Great Britain by Oxford University Press, London

Publication of this book bas been aided by a grant from the Ford Foundation

Library of Congress Catalog Card Number 63-20769

Printed in the United States of America 
TO MY FATHER

JACOB A. JENSEN

( I 883-I96I) 
